\title{
Epidemiologie en prehospitale triage van polytraumakinderen in de regio van Traumacentrum West-Nederland
}

Met belangstelling las ik het interessante artikel van Van Embden e.a. in het Nederlands tijdschrift voor Traumatologie van december 2007 (Ned Tijdschr Traum 2007;15:I73-8I), getiteld: 'Epidemiologie en prehospitale triage van polytraumakinderen in de regio van Traumacentrum West-Nederland'. De conclusie van dit onderzoek is dat er in die regio sprake is van $50 \%$ ondertriage. Dat betekent dat de helft van de kinderen met levensbedreigende letsels niet direct naar het traumacentrum wordt gebracht. Bij het lezen van een dergelijke conclusie rijst de vraag waarop deze is gebaseerd.

De bedoeling van triage is om op straat de ernstige van de minder ernstige traumaslachtoffers te scheiden en deze vervolgens al dan niet naar een traumacentrum te vervoeren. In termen van klinische effectiviteit gaat het dus om de precisie van de triage, uitgedrukt in sensitiviteit en specificiteit. ${ }^{.} \mathrm{Op}$ die manier kan een $2 \times 2$-tabel worden gemaakt (tabel $I$ ).

\begin{tabular}{lll}
\hline & Vervoer naar traumacentrum & Vervoer niet naar traumacentrum \\
\hline $\begin{array}{l}\text { polytraumapatiënt } \\
\text { geen polytraumapatiënt }\end{array}$ & $\begin{array}{l}\text { correcte triage } \\
\text { overtriage (vals positief) }\end{array}$ & $\begin{array}{l}\text { ondertriage (vals negatief) } \\
\text { correcte triage }\end{array}$ \\
\hline
\end{tabular}

Tabel I. 2×2-tabel met als ziektekenmerk het vervoer naar het traumacentrum en polytraumapatiënt volgens de definitie van de ISS als testuitslag.

In deze retrospectieve studie is echter een ander soort $2 \times 2$-tabel gemaakt waarbij de prehospitale traumascore gekoppeld is aan de Iss. Dat levert de volgende 2×2-tabel op (tabel 2).

\begin{tabular}{lll}
\hline & Polytraumapatiënt ISS I6-75 & Geen polytraumapatiënt ISS I-IS \\
\hline RTS < I2 & 40 & I5 \\
RTS = I2 & 40 & 65 \\
\hline
\end{tabular}

Tabel 2. 2×2-tabel met als ziektekenmerk de polytraumapatiënt volgens de definitie van de ISS en de prehospitale traumascore als testuitslag.

Als deze tabel wordt ingevuld met de gegevens uit de studie, geeft dat een sensitiviteit van $40 /(40+40)=50 \%$; een specificiteit van $65 /(15+65)=81 \%$; een fout-negatieve proportie (I-sensitiviteit $=$ ondertriage) van $50 \%$ en een foutpositieve proportie $(\mathrm{I}$-specificiteit $=$ overtriage $)$ van $19 \%$.

Op basis van dit onderzoek kan dus hooguit worden gesteld dat de prehospitale traumascore RTS (Revised Trauma Score) in de helft van de gevallen niet overeenkomt met de ernst van het trauma volgens Iss. Dat zegt echter nog niets over de triage, want die gaat over het transport al dan niet naar een traumacentrum. Daarover is in dit onderzoek onvoldoende informatie beschikbaar. Als van alle patiënten niet alleen de Iss bekend is maar ook naar welk ziekenhuis ze vervoerd zijn, dan kan met die gegevens tabel I worden ingevuld en een betrouwbaar beeld worden geschetst van de kwaliteit van de triage in die regio.

\section{J.P. Frölke, chirurg, Universitair Medisch Centrum St. Radboud, Nijmegen}



ons artikel.

De analyses van ons onderzoek waren gericht op de vraag in hoeverre polytraumakinderen (ISS > I5) op straat te identificeren zijn met behulp van de Revised Traumascore (RTS) en de Pediatric Traumascore (PTS). Ons onderzoek was niet gericht op de vraag of polytraumakinderen in onze regio daadwerkelijk naar het traumacentrum zijn gebracht. We vermelden wel dat $93 \%$ van de polytraumakinderen met een RTS < II, het huidige triagecriterium in onze regio, direct naar het traumacentrum is vervoerd. Als aanvullende informatie geven we in tabel I, zoals voorgesteld door collega Frölke, het percentage daadwerkelijke triage naar het traumacentrum in onze regio.

Tabel I. Vervoer per ambulance direct naar bet traumacentrum of een regioziekenhuis.

\begin{tabular}{llllllll}
\hline \multicolumn{1}{c}{$\begin{array}{l}\text { vervoer naar } \\
\text { traumacentrum }\end{array}$} & $\begin{array}{l}\text { vervoer naar } \\
\text { regioziekenhuis }\end{array}$ & totaal \\
\hline ISS I-IS & geen polytraumapatiënt & 456 & $35,5 \%$ & 828 & $64,5 \%$ & I284* & IOO,0\% \\
ISS > I5 & polytraumapatiënt & 63 & $78,8 \%$ & I7 & $21,3 \%$ & 80 & IOO,0\% \\
\hline
\end{tabular}

* Van 369I/4557 non-polytraumakinderen (ISS I-IS) ( $8 I \%$ ) was het vervoer bekend. Van deze $369 I$ patiënten bleken er 1407 per ambulance te zijn vervoerd (38,I\%). De meerderheid van deze patiënten (I284/I407, 9I.3\%) werd per ambulance direct van de plaats van het ongeval opgehaald en naar het traumacentrum of een regioziekenhuis vervoerd.

Het blijkt dat de meerderheid (79\%) van de polytraumakinderen direct naar het traumacentrum is getransporteerd. Zeventien polytraumakinderen werden naar de SEH van een regioziekenhuis gebracht. Een van deze kinderen overleed na reanimatie binnen dertig minuten op de SEH en elf kinderen werden direct doorverwezen naar een traumacentrumziekenhuis of een brandwondencentrum $(n=2)$. Vijf van de zes kinderen die direct naar het TCWN werden overgebracht, zijn uiteindelijk naar huis ontslagen. Deze kinderen lijken, in termen van mortaliteit, geen nadelige gevolgen te hebben ondervonden van de primaire opvang in een regioziekenhuis. Waarom bij een deel van de polytraumakinderen gekozen is voor een eerste opvang in een regioziekenhuis, was niet uit de patiëntenstatus of het ritformulier af te leiden.

Samenvattend kan worden gesteld dat de vraag van collega Frölke niet de primaire onderzoeksvraag was en, aangezien het een retrospectief onderzoek betrof, niet zonder meer te beantwoorden is. Wij zijn van mening dat ons onderzoek belangrijke informatie oplevert voor het bijstellen van prehospitale triageschema's.

Mede namens D. van Embden, L.M.S.J. Poelhekke, J.P.M. Hoogeveen, L.M. Sturms en G.N. Jukema. 